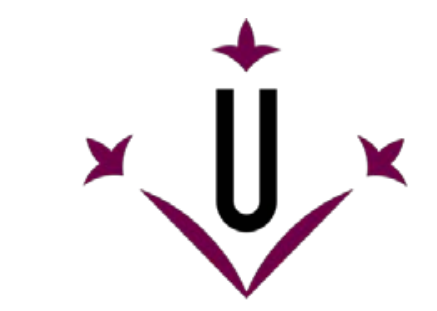

Universitat de Lleida

Document downloaded from:

http://hdl.handle.net/10459.1/67930

The final publication is available at:

https://doi.org/10.1080/14708477.2018.1478848

Copyright

(c) Taylor \& Francis, 2018 


\title{
Undocumented migration, informal economic work and peripheral multilingualism: Challenges to neoliberal regimes?
}

Author's name and affiliation

\begin{abstract}
This article investigates the intersections of immobility and informal work among unsheltered Ghanaians and how these interplay with their multilingual practices. The data include personal-life narratives and informal conversations recorded over a twoyear ethnography in a public-transport bench in the post-industrial Catalan town of Igualada in the outskirts of Barcelona. The study shows that informants practice immobility to gate-keep survival resources; inhabit identities dispossessed of employment and welfare, silencing unregistered economic tasks; and establish nonlegitimised peripheral language hierarchies for intercultural communication yet engage in 'integration-through-national-language' orders. This reveals how undocumented migrants challenge and subvert, while simultaneously perpetuating, the neoliberal exclusionary work/legality conditions and linguistic regimes to which they are subject, which positions them as 'illegal', 'de-killed' and 'languageless' personas, in late capitalism.
\end{abstract}

Keywords: Migration, immobility, informal economy, peripheral multilingualism, neoliberalism

Aquest article investiga com la immobilitat i el treball informal d'un grup de ghanesos sensesostre interseccionen amb les seves pràctiques multilingües. Analitzant narratives de vida i converses gravades durant una etnografia en un banc públic a Barcelona, mostrem com els informants practiquen la immobilitat per regular l'accés a recursos de 
supervivència; s'auto-defineixen com a desocupats sense prestacions socials, silenciant activitats econòmiques no registrades; i, en la comunicació intercultural, estableixen jerarquies lingüístiques deslegitimades que, amb tot, segueixen les normes 'd'integració-via-llengua-estatal'. Es conclou que la immigració indocumentada repta i subverteix, però perpetua, els règims lingüístics i condicions legals/laborals neoliberals precàries que els posicionen com a 'il·legals', 'disfuncionals laborals' i 'des-llenguats' als quals està sotmesa.

Paraules clau: Migració, immobilitat, economia informal, multilingüisme perifèric, neoliberalisme 


\section{Introduction}

The diversification of geographic mobilities and displacements of individuals, along with the intensification of flows of all types of resources around the world, have led to the emergence of heterogeneous societies (Vertovec, 2009). These today are constituted by people who hold various citizenship statuses, and have many work experiences and prospects, family projects, political and religious affiliations, and cultural and language backgrounds (Blommaert, 2013). They get organised in transnational networks that are simultaneously local and international because they hold contacts in their places of birth; in their resident societies; and in other localities where they visited throughout their migratory paths (Castells, 2014). Similarly, they establish socialisation spaces 'off the radar' of governmental authorities, in emplacements (like a bench) that are regulated in connection to, but beyond, across and below, nation-states and supra-national socioeconomic organisations (Glick-Schiller, 2010).

These transnational populations challenge the advanced liberal regimes of neoliberal governments aimed at securing nation-state power, where populations are controlled via bureaucratic systems and registration technologies managed according to the principles of order and rationality (Pujolar, 2007; Rose \& Miller, 2008). These regimes include: citizenship-gatekeeping technologies posing restrictive conditions for accessing legality via visa permits or naturalisations (Inda, 2006); newer work orders and job marketplace dynamics with flexible, tertiarised economic activities (Duchêne \& Heller, 2012), which now defy what counts as 'labour' in exchange for a salary (Vigouroux, 2008), and which interplay with the privatisation and gradual dismantling of welfare structures ('special issue contributor', this volume); and, finally, 'linguistic regimes' (Kroskrity, 2000, p. 3) which have mainstreamed elite multilingual language policies and prolinguistic-diversity discourses but which, in practice, regiment populations through 
monolingual 'integration-through-national-language' rationalities (Krzyzanowski \& Wodak, 2011). My aim in this paper is to contribute to current debates in critical sociolinguistics research (compiled, e.g., in Coupland, 2003, and Canagarajah, 2017) on how nation-state institutions enable, limit, or enforce the spatial, socioeconomic and linguistic im/mobilities of transnational populations. I specifically focus on the extent to which the neoliberal legality regimes, work orders of the globalised new economy, andlanguage regimentation tests to access citizenship described above propels/constrains migrants' lives and leads to the emergence of newer social difference and inequality practices in contexts of precariousness. I do so by exploring how the intersections of transnational immobility and informal economic practices among a small group of unsheltered Ghanaians interplay with their multilingual practices in an alternative socialisation space of a Catalan town.

I first detail the informant-led ethnographic project, and the research space where I conducted this study. I then present the findings (Section 2) and show that informants invest in spatial immobility to gatekeep access to survival resources, including food and information about legality issues. I also suggest that they inhabit identities dispossessed of employment and welfare benefits as a way to account for the informal-work practices that they tend to silence, in turn circulating law-abiding, materially-deprived migrant identities. I finally report on how they establish nonlegitimised language hierarchies including publicly sanctioned translinguistic practices, yet simultaneously engage in 'integration-through-national-language' orders which prescribe monolingualism (whether institutionalised by nation-states or by 'regional' polities). I conclude that this illustrates how undocumented migrants both challenge and perpetuate the neoliberal exclusionary work/legality conditions and linguistic regimes to which they are subject in resident societies (Section 3). I suggest that this contributes to 
understanding how the interplay between immobility, informal work and peripheral multilingualism may generate new knowledge on migrants' alternative transnational organisation practices in under-explored 'contact zones' (Pratt, 1991, p. 33) such as the one described in Section 2.

\section{Theoretical underpinnings}

I approach mobilities as mutually constitutive of spatial, socioeconomic and linguistic demobilisations, dislocations and moorings of a multi-factorial nature (Hannam, Sheller, \& Urry, 2006). I understand 'formal' and 'informal' economy as a continuum in the range of economic practices conducted to sustain a living and to access material resources in the neoliberal marketplace, which challenges perspectives that conceive of informal economy as including 'illegal' work tasks based on underground economic activities (Vigouroux, 2013). This view posits that informal work, like formal work, is socially and linguistically regimented and requires particular social capitals and experiences, including particular language resources. Finally, I adopt and adapt the term ‘peripheral multilingualism' (Pietikainen \& Kelly-Holmes, 2013), originally not applied to migration contexts, to describe informants' non-standard, inextricable amalgamations of communicative frames and allochthonous and autochthonous languages from local and distant contexts. I argue that the spaces where peripheral multilingual practices are mobilised may become 'novel and revealing spaces to examine contemporary complexities in multilingualism' (Pietikainen \& Kelly-Holmes, 2013, p. 5); that is, emplacements where migrants foster newer normativities and linguistic cores based on their delegitimised communicative practices, establishing their 'alternate models of the social world' (Gal, 2001, p. 425) in resident societies. 


\section{Context}

The study took place in Catalonia, a community of about 7.5 million inhabitants located in Spain whose legality system managing transnational populations (ultimately controlled by the Spanish government) is based on controversial migration policies which may allow foreigners to be granted reunification or temporary visa permits without any work authorisations. This is one of the reasons why it has the highest estimated rates of undocumented people in Europe -with a debateable percentage of undocumented migrants of about 30\% (Sànchez, 2008, p. 251).

In terms of language policies and sociolinguistic configurations, Catalonia is officially bilingual in a majority and a minority language: Spanish and Catalan. Spanish is the dominant language of the Spanish nation-state, fuelled by a political and socioeconomic project of 'recentralisation' geared toward Spanish-only policies (Pujolar, 2015), which today includes a language test demanding a basic level of Spanish as a requirement for 'naturalisation' (BOE, 2015, p. 105524). Catalan is a minority language which has been historically persecuted and 'minorised' in the political, economic and sociocultural arenas (Bastardas, 1996). Today it is not recognised as an official language by the European Union, and it is regarded as the coofficial 'vernacular' language of Catalonia, with the Catalan government making attempts to present it as the de-politicised cohesive 'language for everybody' (Generalitat de Catalunya, 2016). Linguistic diversity is recognised, though via 'pragmatic accommodations' (Kymlicka \& Patten, 2003, p. 5) rather than specific language policies protecting migrants' language rights (see Generalitat de Catalunya, 2008). Foreign populations are systematically addressed in, and tend to choose to learn, the majority language first (Pujolar, 2010), to the detriment of Catalan, and to the 
detriment of the migrants' access to local powerful networks in Catalonia, fostering a local Catalan/non-Catalan ethnolinguistic boundary (Woolard, 2016).

The research project took place in a town located an hour from Barcelona City which is illustrative of the sociolinguistic dynamics of Catalan-speaking medium-sized towns with an average rate of foreigners in the metropolitan area of the Catalan capital. It wascalled Igualada and had about 40 thousand inhabitants, $14.7 \%$ of whom consisting of foreigners (the percentage of foreign residents for Catalonia was then $15.7 \%$ ). The first largest migrant group consisted of people born in Africa, the Ghanaian populations presented below being the second largest subgroup after the Moroccans, with 112 single men aged 35-44 (Ajuntament d'Igualada, 2012).

\section{The participants}

The three informants, Alfred, Benedito and Paul (pseudonyms), were, respectively, an English teacher, an accountant, and a schooled cocoa farmer in their forties who were born in an urban town and two villages near Sunyani, the capital of Brong Ahafo, the second largest province in Ghana (West Africa), undergoing mass emigration (Pierre, 2012). Between 2000 and 2001, trying to find job opportunities in Europe and to protect their transnational family income from religious violence in their region (described in Tsikata \& Seini, 2004), the three moved to Southern Spain and started working in the agriculture sector, frequently visiting their relatives in Ghana, and in Italy and the Netherlands. Later on, they moved to Catalonia, pursuing socioeconomic improvement, informed by other Ghanaian acquaintances who had followed similar work-related migratory paths. Benedito and Paul settled in Barcelona City, and Alfred moved to Lleida (Northern Catalonia) to pick fruit. Between 2004 and 2007, they decided to move to a smaller yet still well-connected town, Igualada, where they expected to become 
labour workers in the industry sector, and where they met each other for the first time. There they employed the most widely spoken, prestigious variety of the Akan language, Ashanti, as a lingua franca among themselves. They also spoke other African languages such as Akyem, apart from English and Spanish, and had a command of Catalan and Arabic.

They chose Igualada because it then was one of the biggest centres of the Catalan textile industry and the first tanning market of the Iberian Peninsula. They found employment upon arrival and obtained/renewed their temporary residence visas. In 2010, however, the local industry collapsed and most factories were dismantled. Informants became unemployed and started participating in informal economic practices. They had received some severance payments, though when I met them they no longer had any formal source of income. Their transnational mobilities became very limited, too (none had visited Ghana since 2008). By the end of the fieldwork, they could no longer rent a room and became unsheltered. They took refuge on the bench of an open-air public transport area located on the outskirts of the town; a socialisation space where they networked daily, under precariousness conditions.

\section{Methods and data}

The data were gathered between July 2012 and January 2013 by means of a network ethnography. This included not only active participant observation of social life on their bench but also 'co-ethnographic visits' (Convey \& O'Brien, 2012, p. 339) (i.e. journeys on foot with the informants) to the places of socialisation that informants mentioned during the research project (e.g. the mosque), all located at a 20-minute walk from one another (for the details on this ethnographic method see 'author', in Press). 
I had observed the informants for a year on my way to the bus station, where we had short conversations. I introduced myself as a Catalan English 'teacher' wanting to investigate the languages of migrants in town. They were unimpressed by the university certificates with the project information, and verbal informed consent to participate in the study was not granted until they saw that I did not work for the town hall or for any local NGO, because they mistrusted both. ${ }^{\mathrm{i}}$

I did not command their African languages, and I introduced myself in Catalan, and then in English and in Spanish. This was a marked sociolinguistic comportment, for, as stated above, migrants expect locals to use Spanish with them, providing evidence that it is Spanish which is conceived of as the 'language of integration' indexing a 'right to naturalisation' and 'proper citizenship behaviour' (Pujolar, 2007). This explains why informants' preferred language choice for interviews was Spanish (and, less frequently, English, with extensive codeswitching).

The data collection was as follows. Over six months, I audio-recorded narrative interviews, here understood as self-reflective, transformative communicative events (De Fina \& Perrino, 2011), on the following narrative themes: geographic im/mobility; un/employment; non-legality; social relationships and identities and multilingualism. I approached the personal autobiographical narrative moments which emerged in interviews as social acts unveiling how informants negotiated who they were, at a given time and space (Bamberg, De Fina \& Schiffrin, 2007); i.e., as venues into how they apprehended spatial fixity, unemployment and linguistic delegitimisation.

\section{Findings}

\section{Immobilities}


In interviews, the most salient narrative theme on which migrants topicalised was spatial immobility. They presented their routines in Igualada as if being limited to the habitation of the bench, constructed as a protective 'safe mooring space' (Hannam et al., 2006, p. 2). This is illustrated in Excerpt (1), taken from 'author' (see transcription conventions in the Appendix).

\section{Excerpt (1)}

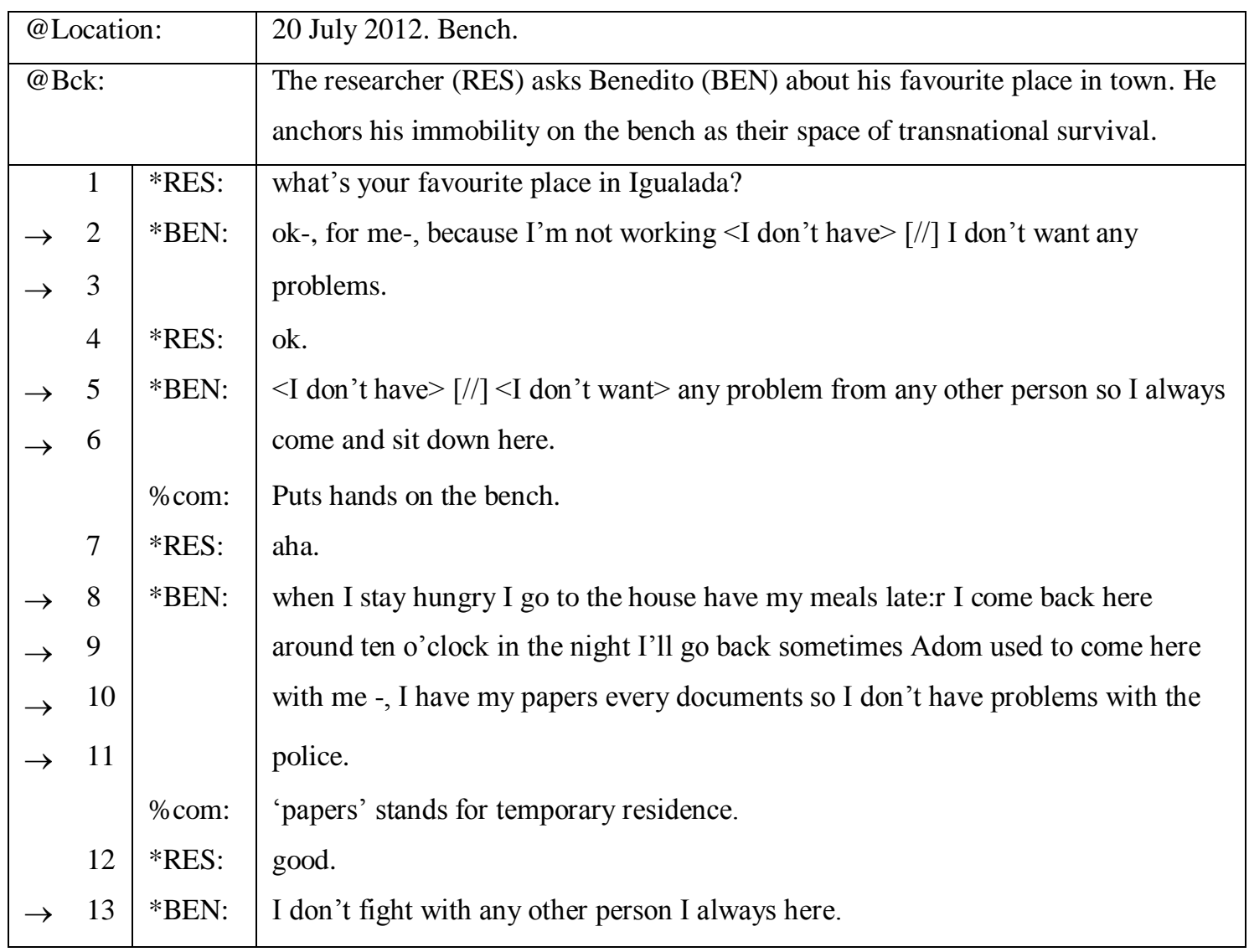

In Excerpt (1), Benedito grounds his local sociospatial orientations on the bench by using: deictically anchored (durative/iterative) proximal verbs like 'sit down' (line 6) and 'come back' (line 8); proximal locative adverbs like 'here' (in lines 6, 8, and 13); and temporal frequency adverbs that mean 'every time'/'all the time', like 'always' 
(lines 5 and 13), used repeatedly and emphatically, as a way to give coherence to his relocation story.

Benedito presented himself as a passive, victimised narrator and as a compliant, 'unproblematic' migrant in front of the researcher. He thematically links his enacted immobility to three narrative focuses of concern which were also taken up by the other informants. Firstly, he presents the bench as the place where to overcome precariousness after long-term unemployment (line 2) and where to secure transnational living under the protective umbrella of the group (line 9). Secondly, he focuses on his temporary 'legal' citizenship status, and presents the bench as a place where to avoid 'problems' with registration authorities like the police (lines 3, 5, 10, and 11) or other unnamed migrants (lines 5 and 13).

Paul linked his unshelteredness to work constraints as well. He inhabited a 'docile' migrant identity by presenting himself, seemingly apologetically, as an individual without the 'transcultural capital' (Kiwan \& Meinhof, 2011) - the knowledge/experience - required to follow migratory paths successfully; almost as a self-delegitimised, 'non-competent' Self who in the past made 'wrong' transnationallife choices. This is seen in Excerpt (2), where he defines himself as 'not knowing anything' about 'Europe', distortedly imagined, he claims, as the provider of 'much money' (line 2), through repetitions (lines 4 and 6). He explains that, because he did not pay taxes in 2008 (when he was employed), he was not eligible for social benefit payments (lines 7, 8 and 11) (apparently he still had to pay his pending taxes). Timely tax non-payment is emphatically constructed as 'foolishness' (lines 15, 17 and 19).

Excerpt (2)

\begin{tabular}{l|l} 
@Location: & 18 July 2012. Bench.
\end{tabular}




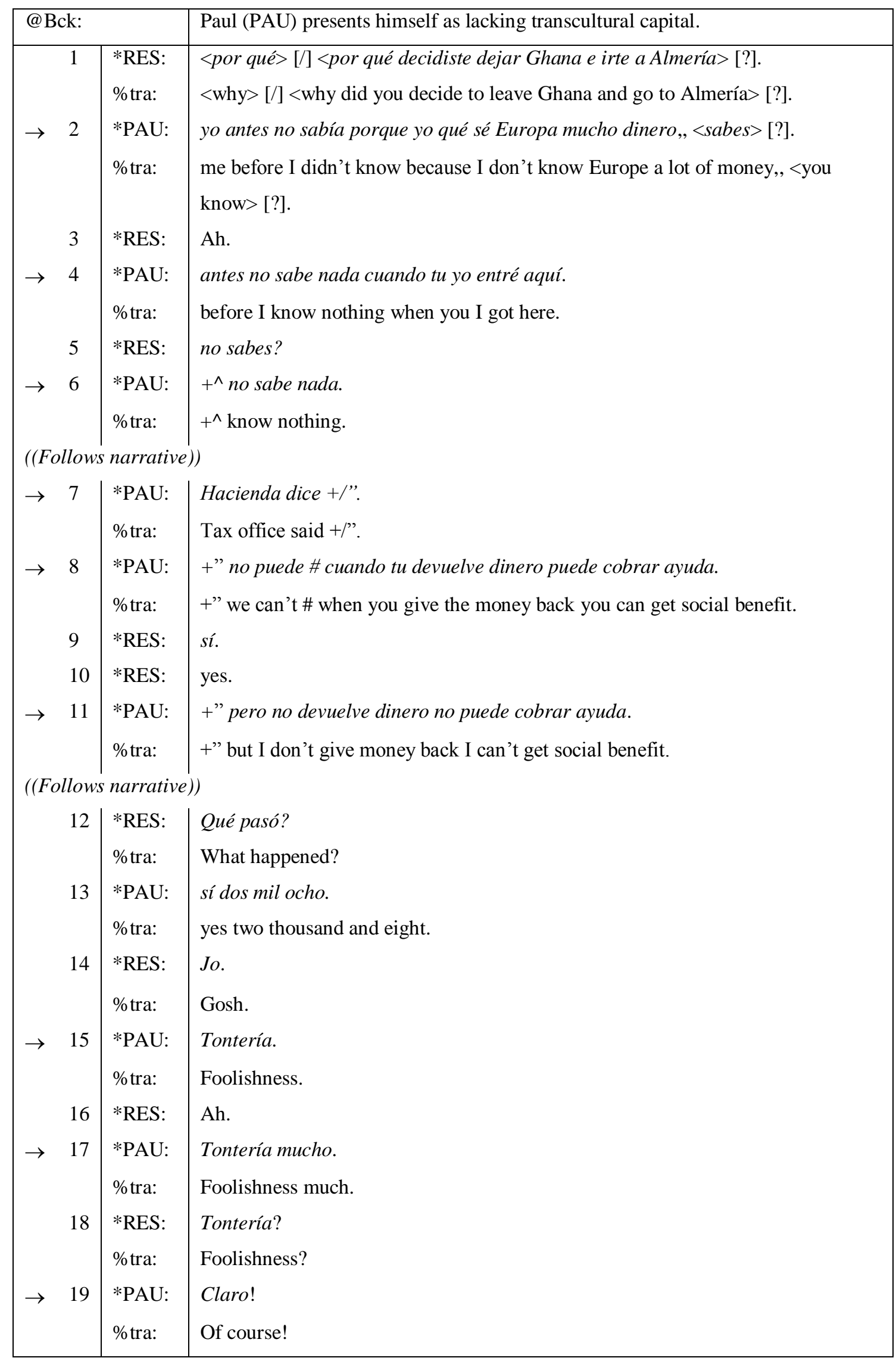


Benedito and Paul present immobility as an enforced way-out to 'macro' socioeconomic constraints, and claim to have made 'wrong' use of (misunderstood) host-society economic rationalities. This seems to have led to some sort of acceptance, in self-blame acts, of a socioeconomic/geographic fixity position on the periphery. The temporary, quiet habitation of the bench is a way for informants to self-attribute 'non-disturbing' migrant identities deserving social aid.

All this reinforces an ethnocentric, moralising narrative on how migrant personas from the imagined 'underdeveloped' South end up entangled in the North because 'they do not know better' (see Smith \& Sparkes, 2008). Evidence of this is the fact that informants presented themselves as itinerant populations with no reterritorialisation projects (and with no projects to 'use up' resident-society resources), as when Paul stated 'I want to go and stay in my country for good I go I don't want to come here again because Europe is not like before' (interview 18 July 2012).

Despite these claims, though, the bench had become an alternative 'shelter' where emplacement practices unfolded. These included, for example, 'tactics' to gain access to a bed when being ill; to cheap international calls, and to media information, as when a local resident allowed them to sleep on the floor of his local shop, when the Pakistani call-shop owner offered special offers to call Africa, or when the bar owner allowed them to watch TV with no purchase obligation. Thus, the bench was actually a space whereby resources for transnational life were gatekept and redistributed not only among locals and migrants but also across different migrants groups. All in all, this shows that immobilities, as discourse and as practice, are a way to strategize with precariousness in order to secure transnational living and to counteract circulating images of unsheltered migrants as 'wrong-doing wanderers'. 


\section{Informal work}

Informants topicalised, too, on their unemployment conditions and socioeconomic stagnation. They mobilised a narrative linked to their work trajectories constructed discursively in three stages, including a successful past period of work, followed by unemployment, and leading to the engagement with informal work (see compilations in Baynham \& De Fina, 2005, for work-related mobilities, too).

In 2008, Alfred started working in a tannery; Benedito, in a foundry; and Paul, in the construction sector. Alfred explains how this added to his previous positive work experience in Catalonia and allowed him to send remittances to his wife in Ghana, in Excerpt (3), illustrative of the first stage of 'success'.

\section{Excerpt (3)}

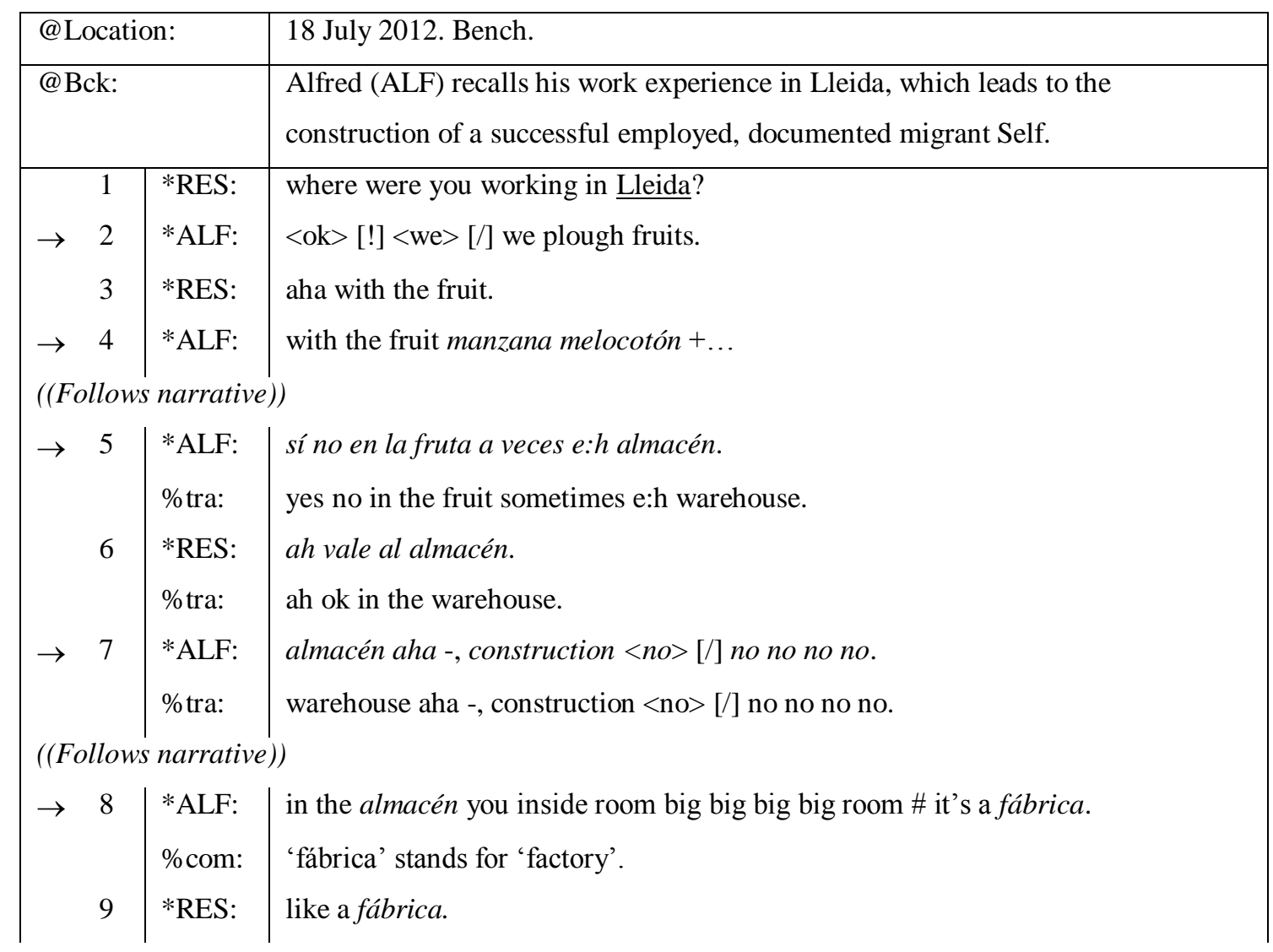




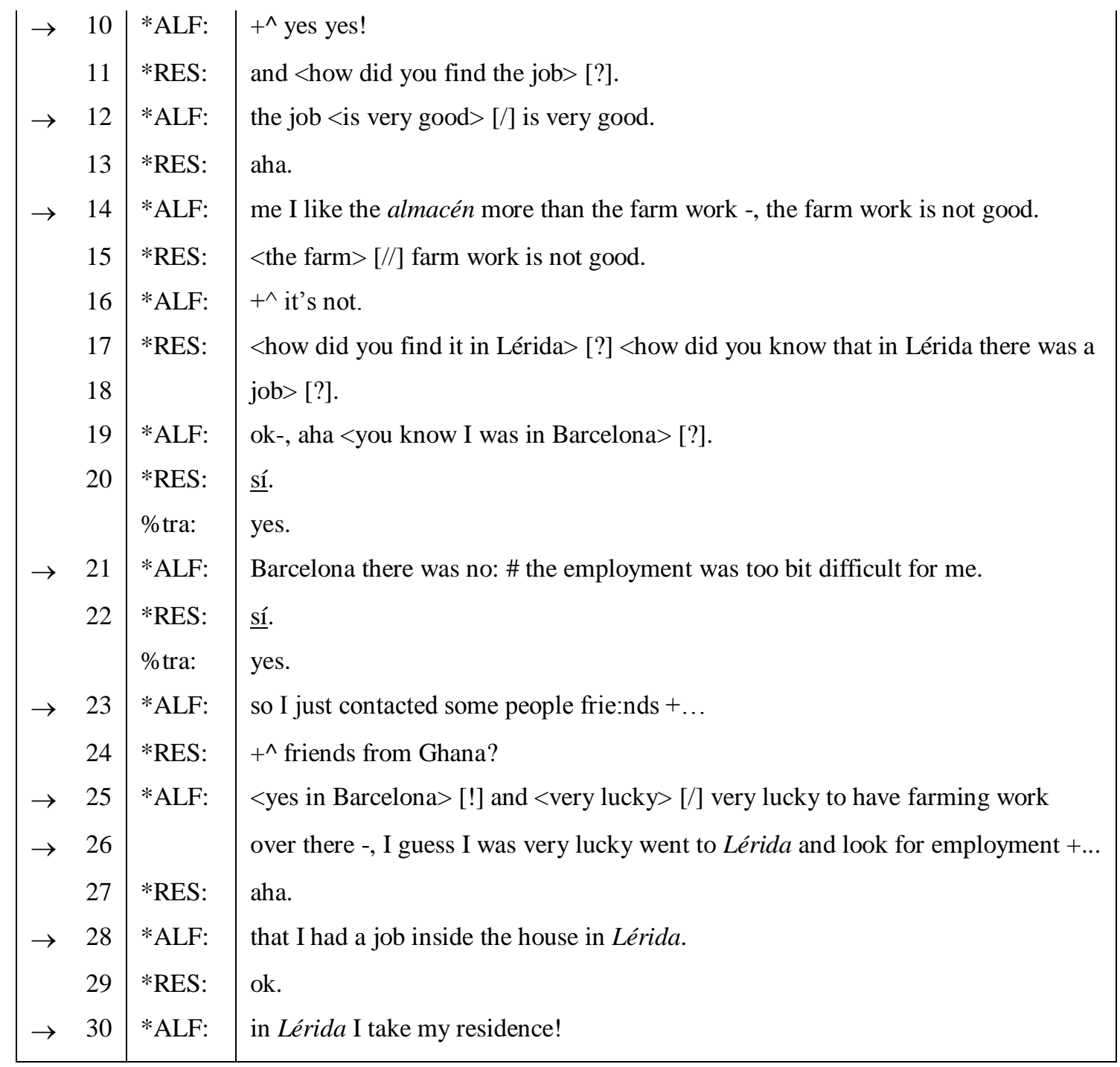

In Excerpt (3), Alfred explains how he, like Benedito, was hired in the local fruit sector in Lleida (lines 1, 4 and 5, and 25-26). His job tasks took place inside a warehouse organised in a taylorised, factory-like, manner (lines 5, 8 and 10), in a protected building (line 28), narrated as being much better than outdoors farming (lines 12 and14) and other jobs in the construction sector (line 7).

Alfred recalls this work experience as a turning point in life; as a moment of relocalisation. He states that this work-motivated trajectory allowed him to get away from a burdensome life in Barcelona (line 21), and to gain networking capital to establish contacts with other Ghanaian acquaintances, who, in turn, provided him with more job prospects (line 23) - bearing witness to the importance of the informal 
networks of support to access employment (Ajenjo et al., 2008). Finally, he highlights that with this first contract he became temporarily documented for the first time (line 30).

Alfred's 'there-and-then' narrated slices of work experiences allow him to selfattribute a resourceful, determined migrant identity capable of navigating neoliberal economic rationalities, because he presents himself as a person who in the past made the 'right' transnational-life choices. This serves to show that his 'here-and-now' present immobilities are mostly the result of structural economic realities, since he had already 'shown' his work abilities (counteracting the self-blame acts previously discussed).

In 2010, Igualada was struck by the Spanish economic crisis. The leather and tanning industries, as well as the construction sector, collapsed, and the region experienced the highest percentage of employment loss in Catalonia, the most affected by it being foreign workers, whose unemployment rate reached $37.1 \%$ (Galí Izard \& Vallès, 2010), at a time when, in Catalonia, it was 22\% (Comissió Obrera, 2011, p. 16). This second period was presented as a stage of de-skilling, illustrated by Benedito in Excerpt (4).

Excerpt (4)

\begin{tabular}{|c|c|c|}
\hline \multicolumn{2}{|c|}{ @Location: } & 18 July 2012. Bench. \\
\hline \multicolumn{2}{|l|}{ @ Bck: } & Benedito (BEN) and Paul (PAU) co-construct a narrative of the Self based on \\
\hline \multirow[t]{2}{*}{$\rightarrow \quad 1$} & *BEN: & ya está yo no cobro paro yo no cobra ayuda! \\
\hline & $\%$ tra: & that's it I don't have unemployment benefit I don't get social benefit! \\
\hline \multirow[t]{2}{*}{2} & *RES: & no tienes paro? \\
\hline & \%tra: & you don't have unemployment benefit? \\
\hline \multirow[t]{2}{*}{$\rightarrow \quad 3$} & *BEN: & nada nada! \\
\hline & \%tra: & nothing nothing! \\
\hline
\end{tabular}




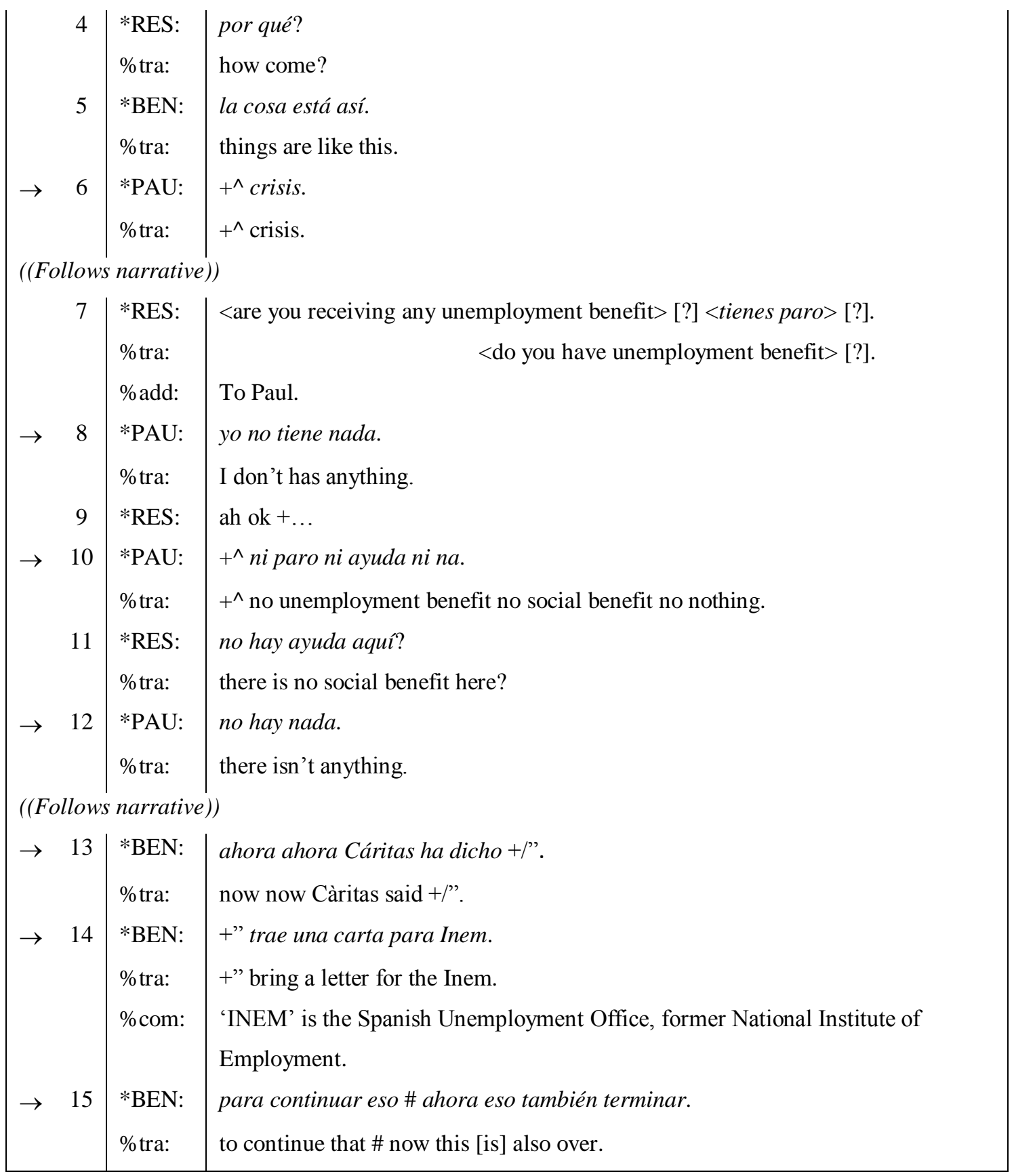

Benedito addresses unemployment by making extensive use of simple negative sentences with the adverbial negative particle 'no' in Spanish (e.g. 'I don't get'; line 1), and with indefinite negative pronoun meaning 'emptiness' ('nothing'; in line 3). Later, Paul, in an overlap, shows alignment with Benedito by presenting himself as a declassed worker living under similar critical conditions, voicing that their troubling experiences were linked to the economic crisis which struck the town (line 6) via simple negative 
statements and repetitions of 'anything' (lines 8, 10 and 12). When I asked whether they received unemployment severance payments, to which both informants replied negatively, Benedito explains that social benefits are no longer available (particularly the 'PIRMI', a temporary minimum 'incorporation' payment of about $420 € /$ month), due to financial cuts (lines 13-15). He names Càritas, the official confederation of charities of the Spanish Catholic Church, as the manager of the bureaucracy required to gain access to PIRMI; i.e., as the social agent participating in the regulation of migrants in neoliberalism. This bears witness to the dismantling not only of the Spanish/Catalan welfare systems but also of the ancillary branches to which their social-service administrations were outsourced. Informants kept their former workmates' telephone numbers and were in touch with four temporary-work agencies. They were offered the possibility to plough fruit in Lleida over a summer, which they refused mainly due to health issues (one of them required hospitalisation due to a heart condition, in 2013).

Between 2009 and 2011, transnational incoming migration to Catalonia stalled, and the numbers of new family reunification petitions and temporary residence permits each decreased by more than 500,000. Besides, 15,581 foreign residents left Catalonia to return to their countries or move to another place (INE, 2011, p. 3). This was not the case of the informants, who could no longer travel freely around Europe with their nonrenewed temporary visas. In this third stage, narrated as a spiral of socioeconomic downwardness, informants engaged in informal economic activities.

Data on transnational informal work and on its impact on migrant populations tend to be controversial and difficult to access (Vigouroux, 2013). There seems to be agreement, though, that local populations also engage in it, and that migrants organise unregistered economic activities in socialisation spaces where the 'grey market' already existed (Sànchez, 2008), contravening discourses presenting migrants as the promoters 
of 'illegality' enclaves. In terms of numbers, at the time of fieldwork it was estimated that approximately half a million migrants worked in the Spanish informal economy (Carrasco Carpio \& García Serrano, 2012, p.15), which translated into about $18 \%$ of the foreign population in Catalonia (Sànchez, 2008, p. 252). I found no data for Igualada, and I could only observe the informants' engagement in it partially, since they warned me to stay away from their 'unregistered' work. I could see (and they did not hide) that they got involved in scrap-selling, by first collecting it from garbage containers, individually, in rotating turns. They also begged in the car park of the supermarket located in front of the bench. Supermarket clients frequently gave them bread and tuna, and the 50-cent coins of their shopping carts.

The only indirect comments that I recorded concerning informal work seemed to indicate that the informants' access to it was a source of competition and contempt. When I inquired about the other informants' economic positions individually, they tended to use reproachful comments to position themselves as being more disadvantaged than the others. For example, when I asked Paul about Alfred, he stated 'él bebiendo un poco \# él tiene vino para beber' ('he drinking a bit \# he's got wine to drink'), seemingly categorising whom he called his 'paisano' ('compatriot') as a drinker not totally ready for formal work (interview 18 July 2012) - in turn positioning himself as more morally righteous than him. And when I asked him about Benedito, Paul stated that he did not need to engage in informal work so frequently because he was already 'better-off': 'éste tiene dinero! [...] él cobra ayuda!' ('this one's got money! [...] he gets social benefit!'). On the grounds of this, I argue that the network under study functioned as an economic unit based on simultaneous comradeship/competition and trust/mistrust; that is, as a 'togetherness of loners' (Bauman, 2001, p. 68) where the ultimate goal was individual transnational survival and 
socioeconomic security. Informal-work practices were part of interested chains of exchanges in which money was not always involved, since food-for-cigarettes exchanges, for instance, were as important as getting a 'turn' to beg in the supermarket. All in all, the informal economy, as discourse and as practice, is the informants' way to claim that structural economic constraints precluded access to formal jobs, despite their proved predisposition and 'skills' for them. It also serves to claim right to social benefits on the grounds of this former contribution to the local economy, and it reinforces the image of the dispossessed migrant Self (with the informants' compliance

to their 'de-skilling' as only labour-work candidates). This unveils the socioeconomic benefits of engaging with spatial immobility on the bench that were left unmentioned when narrating immobility.

\section{Peripheral multilingualism}

On the bench, informants managed intercultural communication within and across migrant groups through the mobilisation of hybrid, truncated multilingual resources and unorthodox translinguistic practices, establishing alternative language hierarchies.

These were grounded mostly upon Spanish as a lingua franca, and upon unconventional English/Spanish codeswitching, as illustrated in statements like 'Ok-, that one eh español es muy difícil eh!' ('Ok-, that one [language] eh Spanish is very difficult eh!') (interview with Paul, 20 July 2012).

The bench was demarked as an Ashanti-speaking zone. Evidence of the informants' linguistic dominion over it is the fact that the Senegalese who came by to access information about legality issues, etc., acknowledged that it was 'the Ghanaians' place' by greeting them with the Ashanti salutation 'bone nnim' ('no problem'), recorded in spontaneous interactions. The few Spanish-speaking local residents who 
contacted the informants (for similar matters) employed an Ashanti expression, too, routinely; in this case, 'ye be hyea' ('we will meet again').

Arabic also had its material and symbolic presence. Informants used Arabic salutations like 'As-salam alaikum' ('peace be with you'), inserted in Ashanti and/or English interactions, in order to show deference to other Ghanaian and Pakistani Muslims. They also employed Arabic insults like 'A'azi' ('nigger'), ambivalently, as a term of reference for their Moroccan acquaintances, with whom most conversations occurred in non-standard Spanish -voicing their inter-group competition for transnational resources (see 'author).

While it is pejoratively considered 'immigrantese' talk or a mixture of 'notquite-languages' (Gal, 2006, p. 15), peripheral multilingualism with translinguistic practices such as the ones described above may be counterhegemonic, because it subverts the dominant sociolinguistic orders of resident societies, transgressing the ideological foundations of the 'native speaker' and challenging 'ownership' conceptions of languages (Makoni \& Pennycook, 2012). In this sense, it makes unrecognised 'nonstandard voices visible/audible' (Jaffe, 2000, p. 498) and puts them at the centre of migrant-regulated spaces, empowering their speakers, usually dispossessed of communicative competence (i.e., 'de-capitalised'; Marti-Rojo, 2010) by society at large (Sabaté Dalmau, Garrido Sardà, \& Codó, 2017). This became evident when informants presented their multilingual resources by first mentioning their invisibilised 'African' languages; in this case, Ghanaian English (GhE); Ashanti, also called Akan or Twi in the region of Brong Ahafo, and Ga, in the Accra area (see Kropp Dakubu, 2015 [1988]). Paul illustrated this by claiming that 'Me I speak only English and Ashanti [...] The same language Ashanti you call it Akan [...] Twi it's the same [...] Accra have another language eh Ga Ga' (interview 20 July 2012). Concerning English, on some occasions 
informants made prevail their 'native' speakerhood and presented themselves as better English speakers than locals, in self-capitalisation acts, challenging the delegitimisation of non- 'inner-circle' English varieties like GhE, derogatorily called ‘broken English' (see Tupas, 2015), as illustrated by Alfred and Paul, in Excerpt (5).

\section{Excerpt (5)}

\begin{tabular}{|c|c|c|c|}
\hline \multicolumn{3}{|c|}{ @Location: } & 18 July 2012. Bench. \\
\hline \multicolumn{3}{|c|}{ @ Bck: } & $\begin{array}{l}\text { Together with Paul (PAU), Alfred (ALF) presents local populations as having no } \\
\text { (or scarce) command of this language. He constructs Spanish as the language of } \\
\text { intercultural communication and self-attributes only receptive knowledge of } \\
\text { Catalan. }\end{array}$ \\
\hline & & *RES: & and in here do they speak English? \\
\hline & 2 & *ALF: & the people here they are not. \\
\hline & 3 & *PAU: & $+^{\wedge}$ small $[/ /]<$ small English $>[>]$. \\
\hline & 4 & *ALF: & $<$ no $>[<]$. \\
\hline & 5 & *ALF: & no only a few people. \\
\hline & 6 & *RES: & only a few people. \\
\hline & 7 & *ALF: & only a few people speak English only few only. \\
\hline & 8 & *RES: & So do you use English when you go here? \\
\hline & & \%com: & 'here' stands for the supermarket area where they met local residents. \\
\hline \multirow[t]{2}{*}{$\rightarrow$} & 9 & *ALF: & No no no. \\
\hline & 10 & *RES: & No? \\
\hline \multirow[t]{2}{*}{$\rightarrow$} & 11 & $* A L F:$ & No no no only the only Spanish. \\
\hline & 12 & $*$ RES: & Only Spanish? \\
\hline \multirow[t]{6}{*}{$\rightarrow$} & 13 & *ALF: & Yes. \\
\hline & 14 & *RES: & And not Catalan? \\
\hline & 15 & *ALF: & Catalan? ok-, Catalan. \\
\hline & & \%com: & He laughs. \\
\hline & 16 & *RES: & Una mica. \\
\hline & & \%tra: & A bit. \\
\hline \multirow[t]{3}{*}{$\rightarrow$} & 17 & *ALF: & If you speak yes it's but I can't reply you in catalán only in castellano. \\
\hline & 18 & *RES: & Vale però tu l'entens? \\
\hline & & $\%$ tra: & Ok but you understand it? \\
\hline & 19 & *ALF: & Yes jo entén entén sí. \\
\hline
\end{tabular}


In Excerpt (5), Alfred, the English teacher, states that local populations do not command English (lines 2, 4 and 5). Paul, in an overlap, shows alignment with Alfred and answers that people in town speak 'small English' (line 3), positioning himself as a 'better' English speaker than them, too. Alfred clarifies, via repetition, that it is just a few who command this language (lines 5 and 7), adding that he does not use it with them (repeating 'no'; lines 9 and 11).

And yet, on other occasions when they made reflexive statements about their English competence in public, they contradictorily downplayed their command of it and ended up denying their native speakerhood condition, in self-decapitalisation acts like the one presented in Excerpt (6).

Excerpt (6)

\begin{tabular}{|c|c|c|c|}
\hline \multicolumn{3}{|c|}{ @Location: } & 20 July 2012. Bench. \\
\hline \multicolumn{3}{|c|}{ @ Bck: } & Paul (PAU) presents himself first as a non-speaker and then as a non-fully \\
\hline & 1 & *RES: & so how many languages do you speak? \\
\hline & & \%com: & Paul laughs. \\
\hline$\rightarrow$ & 2 & *PAU: & no me I don’t speak English. \\
\hline & & \%com: & Paul laughs. \\
\hline & 3 & *RES: & you don't speak English? \\
\hline$\rightarrow$ & 4 & *PAU: & I no speak English \# <why are you> [?]. \\
\hline$\rightarrow$ & 5 & *RES: & $+^{\wedge}$ did you go to school in Ghana? \\
\hline & 6 & *PAU: & why are you saying that? \\
\hline & 7 & *RES: & because I heard you speak English. \\
\hline & 8 & *PAU: & I speak small small. \\
\hline
\end{tabular}

In Excerpt 6, Paul presents himself as speaking 'no English' (lines 2 and 4). I was surprised, because we were actually conversing in this language. After my overlap (line 
5), he explains that he speaks 'small English' (line 8), with emphatic repetition of quantifying determiners ('no' or 'small'), following the aforementioned dominant linguistic ideology conceiving of non-monoglossic Englishes as faulty. This suggests that informants, in fact, participated in established resident-society sociolinguistic orders when regimenting their own talk, which became more evident with the analysis of their practices and ideologies revolving around local bilingualism.

Informants followed an integration-through-national-language ideology and made every attempt to use Spanish with locals and foreign populations (see Excerpt 5, lines 11, 13 and 17). They presented it as the legitimate language of reterritorialisation, and they inserted it in their other languages, as shown in statements dealing with work or legality issues, like 'almacén' and 'fábrica' (Excerpt 3, line 8) -Catalan towns were referred to in Spanish, too, as in the case of 'Lérida' (for 'Lleida'; Excerpt 3, line 28). The Spanish language was also a barometer of 'integration' to be used among themselves and with other migrant groups in linguistic competitions whose aim was to 'assess' who deserved linguistic legitimacy (and recognition) in the resident-society language.

Catalan, was employed as well, because informants engaged in Catalan/Spanish bilingualism, as seen with their systematised use of the greeting 'déu' (equivalent to Spanish 'adiós' - 'bye'). This was so despite their claims to the contrary, for they did not conceive of Catalan as belonging to their networking spaces (or to their linguistic repertoires), even when they were using it to try to access the local marketplace (for example, with their CV translated into Catalan by the temporary-work agency workers). In Excerpt 5 Alfred claims a 'receptive' command of it (line 19), in positivising stances where he makes it clear that the language is 'ok' (line 15) in front of a 'Catalan' researcher. 
All in all, informants' peripheral multilingual practices and ideologies speak of how they navigate translocal language hierarchies, which include: the institutional language testing regimes of the nation-state gatekeeping access to citizenship, like the Spanish language test for naturalisation; the language policies of minority-language societies, like the requirement to hold an intermediate level of Catalan to work in certain areas of the Catalan administration (as in schools); the prevailing sociolinguistic comportments of local residents granting who counts as linguistically legitimated in local networks of support; and, finally, the linguistic markets negotiated within and across transnational populations, frequently hidden from view, who keep crucial transnational-life resources, too. This allows for the visibilisation of the complexities of socialising and networking in the different linguistic markets that migrants face throughout their linguistic incorporation into their resident societies. This entails the management of linguistic practices in spaces where there are local linguistic conflicts concerning the legitimacies of Spanish and Catalan, as in Catalan bureaucracy institutions; and of competitions of linguistic capitals dealing with migrants' languages (i.e., allochtonous languages), as in migrant-regulated spaces such as cybercafés or public benches. Finally, the informants' peripheral multilingual practices also reveal the language resources, language choices and language practices which are relevant for migrants themselves, and for a deeper understanding of their ambivalent social meanings, at the local and global level.

\section{Concluding remarks}

In this paper I have tried to show that current nation-states continue striving to operate as sovereign units and as the ultimate custodians of citizenship rights and citizenship legitimacies (Park \& Wee, 2017), despite the global forces that are destabilising their 
territorial, demographic, socioeconomic and linguistic rationalities, forcing them to adapt (and re-invent themselves) to the 'post-national' era (Heller, 2011).

Spain is an illustrative example of how Southern European nation-states struggle to secure state power while being immersed in this shift towards transnationalisation (Sabaté i Dalmau, 2014). I have argued that it is modernising its institutions, bureaucratic machinery and governance technologies according to the logics of global neoliberalism, as a way to manage the 'external' and 'internal' pressures that now challenge its very foundations under the globalised new economy. These pressures come from supranational institutions like the European Union, for instance, closely supervising its weakened economic position in the global scene; and from 'local' communities like Catalonia, who pushes for political self-determination and emancipation.

The object of this investigation has been another of the biggest challenges to the Spanish nation-state's tenets based on territorial, political and linguistic homogeneity: the heterogeneous transnational networks of people which occurred relatively late and unexpectedly, in Spain as well as in Catalonia. These soon established alternative institutions of transnational life and socialisation spaces catering for transnational survival resources in a subversive manner, off the radars of governance systems and local authorities, which made governmental unreadiness and inefficiency visible. Further evidence of this are the three extraordinary regularisation processes that the Spanish government, with an overloaded bureaucratic system, undertook in 2000, 2001 and 2005 as a way to 'legalise' a mass of undocumented migrants (see Codó, 2008; Kostova Karaboytcheva, 2006).

I have shown that modernisation in Spain led to a neoliberal work-legalitylanguage regimentation triad aimed at targeting non-skilled labour migrants from 
geographical peripheries. Now, one needs to have a work permit in order to access legalisation and 'naturalisation', which is ultimately granted only after a recent official language test in the Spanish language - showing, in turn, that citizenship, also in postnational times, is about language. In this sense, Spanish is taken up to meet the requirements of the Spanish government granting citizenship rights; to fulfil the expectations concerning their linguistic comportments in their localities in Catalonia (where in most cases they are expected not to use the 'locals' autochthonous language and to prove Spanish proficiency, at the workplace as well as in the street); and finally, to navigate the linguistic markets regulated by migrants themselves, where Spanish is frequently employed as the yardstick whereby to navigate competitions of linguistic capitals linked to the attainment of legitimacy to network in such transnational spaces.

A focus on migrants like the single Ghanaian men who meet none of the legality conditions of the triad, immersed in a spiral of structural geographic, socioeconomic and linguistic dispossessions of all sorts, has allowed for the examination of the consequences of advanced liberal governmentality upon people who do not fit, in peripheral research spaces like a bench, which remain largely unchartered. A narrativein-ethnography critical approach to the ways in which the unsheltered make sense of, and mediate, through unemployment, legality limbos, and linguistic de-capitalisations has offered an informant-oriented view on the reproduction of older, and the establishment of new, social inequality practices which may sediment structural marginalisation, locally and transnationally.

The results have provided evidence that migrants' peripheral multilingualism constitutes a 'record' (Blackledge \& Creese, 2017, p. 34) or repository of mobility itineraries, in which transnational work experiences and legality statuses get inscribed, negotiated and re-transported in intercultural communication, making it more evident 
that non-legality, informal work conditions and translinguistic talk are mutually constitutive. In this sense, transnational populations' reflexive narratives around the triad reveal the ways in which they oppose, challenge and try to subvert, but simultaneously, consciously and unconsciously, perpetuate, the neoliberal restrictive work/legality conditions and linguistic regimes to which they are subject. This paradox opens up a new research venue for the investigation of de-skilling, 'illegalisation' and de-languaging among and within demobilised migrant networks, in resident societies with exclusionary borders.

\section{Acknowledgements}

I thank informants for their participation in this project, as well as the contributors to X, for their insightful comments. Any shortcomings are mine.

\section{Disclosure statement}

No potential conflict of interest was reported by the author.

\section{Funding}

This work was supported by X; under Grants X and X; and the X under Grant X. 


\section{Notes}

${ }^{\mathrm{i}}$ The confidentiality of the data as well as the protection of the informants' identities were ensured by the Ethics Committee at University $\mathrm{x}$ (file $\mathrm{x}$ ).

\section{References}

Ajenjo, M., Blanes, A., Bosch, J., Parella, S., Recio, A., San Martin, J., \& Sintes, E. (2008). Les condicions de vida de la població immigrada a Catalunya. Fundació Jaume Bofill - Institut d'Estudis Regionals i Metropolitans de Barcelona.. Editorial Mediterrània.

Ajuntament d'Igualada. (2012). Padrón municipal continuo. Resumen numérico por nacionalidades, 23 November. Town Hall Registry, Igualada.

Bamberg, M., De Fina, A., \& Schiffrin, D. (Eds.). (2007). Selves and Identities in Narrative and Discourse. Amsterdam: John Benjamins.

Bastardas, A. (1996). Ecologia de les llengües: medi, contactes $i$ dinàmica sociolingüística. Barcelona: Proa.

Bauman, Z. (2001). Community: Seeking Safety in an Insecure World. Cambridge: Polity Press.

Baynham, M., \& De Fina, A. (Eds.). (2005). Dislocations/Relocations. Narratives of Displacement. Manchester \& Northampton: St. Jerome Publishing.

Blackledge, A., \& Creese, A. (2017). Translanguaging in mobility. In S. Canagarajah (Ed.), The Routledge Handbook of Migration and Language (pp. 31-46). Abingdon: Routledge.

Blommaert, J. (2013). Chronicles of Complexity: Ethnography, Superdiversity, and Linguistic Landscapes. Bristol: Multilingual Matters. 
BOE. (2015, 7 November). Real Decreto 1004/2015, de 6 de noviembre, por el que se aprueba el Reglamento por el que se regula el procedimiento para la adquisición de la nacionalidad española por residencia. Madrid: Spanish Ministry of Justice. Retrieved https://www.boe.es/diario_boe/txt.php?id=BOE-A-2015-12047

Canagarajah, S. (May, 2017). The Routledge Handbook of Migration and Language. Abingdon: Routledge.

Carrasco Carpio, C. and García Serrano, C. (2012) Inmigración y mercado de trabajo. Informe 2011. Secretaría General de Inmigración y Emigración. Ministerio de Empleo y Seguridad Social. Madrid: Subdirección General de Información.

Castells, M. (Ed.). (2004). The Network Society: A Cross-Cultural Perspective. Cheltenham: Edward Elgar Publishing.

Codó, E. (2008). Immigration and Bureaucratic Control: Language Practices in the Public Administration. Berlin: Mouton de Gruyter.

Comissió Obrera. (2011). Mapa de l'Atur a Catalunya 2011 [Unemployment map of Catalonia].

Convey, I., \& O’Brien, V. (2012). Gypsy-traveler narratives: Making sense of place. A co-ethnography. Narrative Inquiry 22(2), 332-347.

Coupland, N. (Ed.). (2003). Sociolinguistics and globalization. Special Issue in Journal of Sociolinguistics 7(4).

De Fina, A., \& Perrino, S. (2011). Introduction: Interviews vs. 'natural' contexts: A false dilemma. Language in Society 40(1), 1-11.

Duchêne, A., \& Heller, M. (Eds). (2012). Language in Late Capitalism: Pride and Profit. New York, NY: Routledge. 
Gal, S. (2006). Migration, minorities and multilingualism: Language ideologies in Europe. In C. Mar-Molinero \& P. Stevenson (Eds.), Language Ideologies, Policies and Practices (pp. 13-27). Basingstoke: Palgrave.

Gal, S. (2001). Language, gender, and power: An anthropological review. In S. Duranti (Ed.), Linguistic Anthropology: A Reader (pp. 420-430). Oxford: Blackwell.

Galí Izard, J. M., \& Vallès, C. (2010). Informe Econòmic Anual de l'Anoia 2010. Igualada: Gràfiques Cubí.

Generalitat de Catalunya. (2016). El Català, llengua per a tothom. Retrieved from Departament de Política Lingüística: http://www.gencat.cat/llengua/peratothom

Generalitat de Catalunya. (2008). National Agreement on Immigration. An agreement to live together. Retrieved from Departament de Benestar Social i Família:

Glick Schiller, N. (2010). A global perspective on transnational migration: Theorising migration without methodological nationalism. In R. Bauböck \& T. Faist (Eds.), Diaspora and Transnationalism: Concepts, Theories and Methods (pp. 109129). Amsterdam: Amsterdam University Press.

Hannam, K., Sheller, M. \& Urry, J. (2006). Editorial: Mobilities, immobilities and moorings. Mobilities 1(1), 1-22.

Heller, M. (Ed.). (2011). Paths to Post-Nationalism. A Critical Ethnography of Language and Identity. Oxford: Oxford University Press.

Inda, J. X. (2006). Targeting Immigrants: Government, Technology and Ethics. Malden, MA: Blackwell.

INE (2011). Avance del padrón municipal a 1 de enero de 2011. Instituto Nacional de Estadística, Madrid. http://www.ine.es/prensa/np648.pdf

Jaffe, A. (2000). Non-standard orthography and non-standard speech. Journal of Sociolinguistics 4(4), 497-513. 
Kymlicka, W., \& Patten, A. (2003). (Eds). (2003). Language Rights and Political Theory. Oxford: Oxford University Press.

Kiwan, N., \& Meinhof, U. H. (2011). Cultural Globalization and Music: African artists in transnational networks. Basingstoke: Palgrave.

Kropp Dakubu, M. E. (Ed.). (2015 [1988]). The Languages of Ghana. Abingdon: Routledge.

Kroskrity, P. V. (Ed.). (2000). Regimes of Language: Ideologies, Polities, and Identities. Santa Fe, NM: School of American Research Press and James Currey Ltd.

Krzyzanowski, M., \& Wodak, R. (2011). Political strategies and language policies: The European Union Lisbon strategy and its implications for the EU's language and multilingualism policy. Language Policy 10(2), 115-136.

Makoni, S., \& Pennycook, A. (2012). Disinventing multilingualism. From monological multilingualism to multilingual franca. In M. Martin-Jones, A. Blackledge \& A. Creese (Eds.), The Routledge Handbook of Multilingualism (pp. 439-453). Abingdon: Routledge.

Martín-Rojo, L. (Ed.). (2010). Constructing Inequality in Multilingual Classrooms. Berlin: Mouton de Gruyter.

Park, J. S. \& Wee, L. (2017). Nation-state, transnationalism, and language. In S. Canagarajah (Ed.), The Routledge Handbook of Migration and Language (pp. 47-62). Abingdon: Routledge.

Pennycook, A. (2012). Language and Mobility: Unexpected Places. Bristol: Multilingual Matters.

Pierre, J. (2012). The Predicament of Blackness: Postcolonial Ghana and the Politics of Race. Chicago, IL: University of Chicago Press. 
Pietikainen, S., \& Kelly-Holmes, H. (2013). Multilingualism and the Periphery. Oxford: Oxford, NY: Oxford University Press.

Pujolar, J. (2015, May). New speakers and new language conflicts in the Iberian Peninsula. Paper presented at the conference Spanish in Contact: New Speakers in the Spanish-Speaking World, Heriot-Watt University, Edinburgh.

Pujolar, J. (2010). Immigration and language education in Catalonia: Between national and social agendas. Linguistics and Education 21, 229-243.

Pujolar, J. (2007). African women in Catalan language courses: Struggles over class, gender and ethnicity in advanced liberalism. In B.S. McElhinny (Ed.), Words, Worlds and Material Girls: Language, Gender and Globalization (pp. 305-348). Berlin: Mouton de Gruyter.

Rose, N., \& Miller, P. (2008). Political power beyond the State: Problematics of government. The British Journal of Sociology, 173-205.

Sabaté i Dalmau, M. (2014). Migrant Communication Enterprises: Regimentation and Resistance. Bristol: Multilingual Matters.

Sabaté Dalmau, M., Garrido Sardà, M. R., \& Codó, E. (2017). Language-mediated services for migrants: Monolingualist institutional regimes and translinguistic user practices. In S. Canagarajah (Ed.), The Routledge Handbook of Migration and Language (pp. 558-576). Abingdon: Routledge.

Smith, B. \& Sparkes, A. C. (2008). Contrasting perspectives on narrative selves and identities: an invitation to dialogue. Qualitative Research 8(1), 5-35.

Tsikata, D., \& S. Wayo, S. (2004). Identities, Inequalities and Conflicts in Ghana. CRISE Working Paper 5. Retrieved from

Tupas, R. (Ed.). (2015). Unequal Englishes. The Politics of English Today. New York, NY: Palgrave MacMillan. 
Vertovec, S. (2009). Transnationalism. Abingdon: Routledge.

Vigouroux, C. B. (2013). Informal economy and language practice in the context of migration. In A. Duchêne, M. G. Moyer \& C. Roberts (Eds.), Language, Migration and Social Inequalities: A Critical Sociolinguistic Perspective on Institutions and Work (pp. 56-78). Bristol: Multilingual Matters.

Vigouroux, C. B. (2008). From Africa to Africa: Globalization, migration and language vitality. In C. B. Vigouroux \& S. S. Mufwene (Eds.), Globalization and Language Vitality: Perspectives from Africa (pp. 1-31). London: Continuum.

Woolard, K. A. (2016). Singular and Plural: Ideologies of Linguistic Authority in 21st Century Catalonia. Oxford, NY: Oxford University Press. 
Appendix: Transcription system

Interactions are reproduced verbatim

\section{Language coding}

Plain: English

Italics: Spanish

Underlined: Catalan

\section{Transcription conventions}

@Bck: $\quad$ Background information (participants, context and topic)

\%tra: $\quad$ Free translation of the turn for languages other than English

\%com: Comment; contextual information about the previous utterance

\%add: $\quad$ Addressee of the turn

$+^{\wedge} \quad$ quick uptake or latching

$+\% \quad$ quotation in the next line

+" quotation follows

\# $\quad$ pause

[>] overlap follows

$[<] \quad$ overlap precedes

$[/ /] \quad$ reformulation

$\langle>\quad$ scope

: lengthened vowel

((Follows narrative $)):$ turns omitted due to space constraints

\section{Intonation contours}

end-of-turn falling contour 
end-of-turn rising contour

[!] end-of-turn exclamation contour

,

tag question 